ppi $201502 Z U 4645$

Esta publicación científica en formato digital es continuidad de la revista impresa ISSN-Versión Impresa 0798-1406 / ISSN-Versión on line 2542-3185Depósito legal pp $197402 Z$ U34

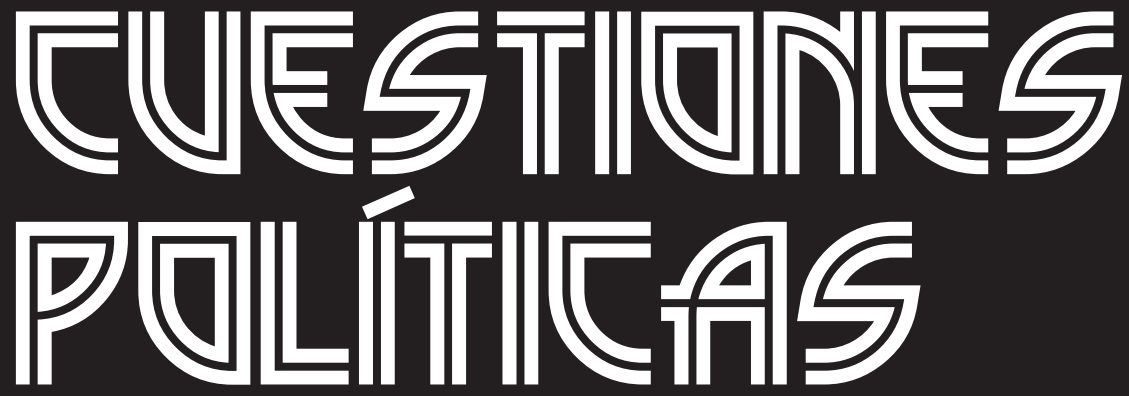

Instituto de Estudios Políticos y Derecho Público "Dr. Humberto J. La Roche" de la Facultad de Ciencias Jurídicas y Políticas de la Universidad del Zulia Maracaibo, Venezuela
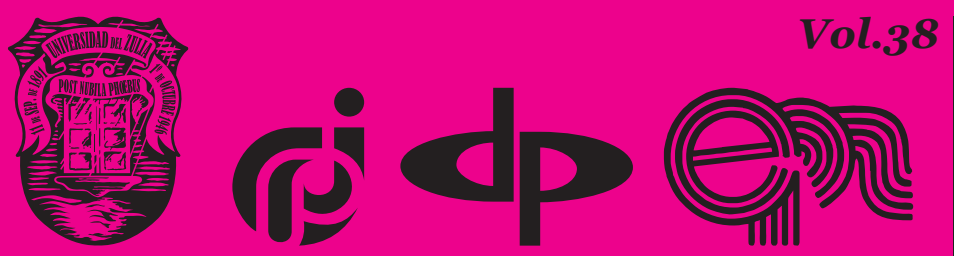

$N^{\circ}$ Especial 1era Parte 2020 


\title{
Contemporary Criminal and Criminal Executive Law Conflicts and Ways of Overcoming Them
}

\author{
DOI: https://doi.org/10.46398/cuestpol.38e.30
}

\begin{abstract}
Alexander Yuryevich Epikhin * Oleg Aleksandrovich Zaitsev ** Sergei Vladimirovich Tasakov ${ }^{* * *}$ Elena Vladimirovna Nechaeva **** Andrey Viktorovich Mishin
\end{abstract}

\section{Abstract}

The article discusses the definition and correlation of the concepts of "conflict" and "competence" and provides various expert opinions on this. In the methodology it is an analytical research based on documentary. In modern scientific literature, the clash of the rules of criminal law is called conflict of laws, using the definitions indicated as identical concepts. However, the authors point to the controversial nature of such an interpretation of those concepts. The causes of conflicts in the rules of Russian law are analyzed. Thereis also a detailed analysis of conflicts in the rules of domestic criminal law and criminal executive law. In the context of the topic studied, the authors refer to the categories of criminal law and criminal executive law as the principles of criminal law. It emphasizes by way of conclusion that the conflicts identified are not an exhaustive list, simply the authors of this work managed to consider only some aspects of the subject, therefore

* Professor, Doctor of Law, Professor the Department of Criminal Procedure and Forensics, Kazan Federal University Tel.: 8987976543. ORCID ID: https://orcid.org/oooo-0oo2-2193-1002. Email: doc@epihin.ru

** The Institute of Legislation and Comparative Law under the Government of the Russian Federation, Professor, Doctor of Law, Chief Researcher, Department of Criminal, Criminal Procedure Legislation; Judicial System ISP, Vice-President of the Union of Criminologists and Criminologists. ORCID ID: https://orcid.org/oooo-0002-2193-1002. Email: oleg010663@mail.ru

*** Doctor of jurisprudence, associated professor (The Federal State Budgetary Educational Institution of Higher Education "Chuvash State University by I.N. Ulyanov, Tel.: 8(960)3050195, The Federal State Budgetary Educational Institution of Higher Education "Chuvash State University by I.N. Ulyanov". ORCID ID: https://orcid.org/oooo-0003-3355-976X. Email: tasakov@mail.ru

${ }^{* * * *}$ Candidate Degree (Juridical Sciences), Associate Professor (The Federal State Budgetary Educational Institution of Higher Education "Chuvash State University by I.N. Ulyanov"), The Federal State Budgetary Educational Institution of Higher Education "Chuvash State University by I.N. Ulyanov". ORCID ID: https://orcid.org/oooo-0001-8742-1905. Email: nechaeva_ev@mail.ru

$* * * * *$ Associate Professor, Candidate of Law, Professor, Department of Criminal Procedure and Forensic Science. ORCID ID: https://orcid.org/oooo-0oo1-5453-9536, Kazan Federal University. Email: avmishel@mail.ru 
the conclusions and suggestions are not indisputable. In any case, the discussion of these issues is important to achieve coherence in the rules of criminal law and criminal executive law.

Keywords: collisions in criminal law; executive criminal law; causes of conflicts in legal hermeneutics; examples of criminal disputes; conflict resolution methods.

\section{Conflictos contemporáneos del derecho penal y ejecutivo penal y las formas de superarlos}

\section{Resumen}

El artículo analiza la definición y correlación de los conceptos de "conflicto" y "competencia" y brinda diversas opiniones de especialistas al respecto. En lo metodología se trata de una investigación analítica de base documental. En la literatura científica moderna, el choque de las normas del derecho penal se denomina conflicto de leyes, utilizando las definiciones indicadas como conceptos idénticos. Sin embargo, los autores señalan la naturaleza controvertida de tal interpretación de estos conceptos. Del mismo modo, se examinan las causas de los conflictos en las normas de la legislación rusa. También se realiza un análisis detallado de los conflictos existentes en las normas del derecho penal interno y del derecho ejecutivo penal. En el contexto del tema estudiado, los autores se refieren a las categorías de derecho penal y ejecutivo penal como los principios del derecho penal. Destaca a modo de conclusión que los conflictos señalados no son una lista exhaustiva, simplemente los autores de este trabajo lograron considerar solo algunos aspectos del tema, por tanto, las conclusiones y sugerencias no son indiscutibles. De cualquier modo, la discusión de estos temas es importante para lograr coherencia en las normas del derecho penal y del derecho ejecutivo penal.

Palabras clave: colisiones en derecho penal; derecho penal ejecutivo; causas de conflictos en hermenéutica jurídica; ejemplos de conflictos penales; métodos de resolución de conflictos.

\section{Introduction}

More than twenty years have passed since the criminal and criminal executive code has been adopted. Numerous changes and amendments 
Elena V. Mischenko, Maxim S. Fabrikov, Elena V. Martynenko, Stanislav E. Martynenko, Viktor M. Smirnov, Gulnara R. Ibraeva y Andrey V. Kosenko

Young People Leisure Activities Transformation During Quarantine Self-Isolation: Characteristics 456 and Regulation Problem.

made during this time to these laws number in the hundreds. On the one hand, this circumstance indicates a continuous process of improving the criminal and executive criminal law of the Russian Federation related to dynamically developing public relations, on the other hand, it entails the emergence of new inconsistencies and contradictions, the identification of new conflicts that require focused work on their elimination. Consistency, soundness of legislation, lack of drawbacks in it are the key to a harmonious, effective law enforcement activity. For criminal and criminal executive law, which contains the most stringent measures of state coercion, the achievement of such consistency is of particular relevance. It is precisely from the point of view of their punitive content any imbalance can lead to a substantial violation of the rights and freedoms of human and citizen.

The term "conflict" has long been known to the law (the first references were met in the Code of Laws (1550) (Ufimtseva, 2019), but its single and unambiguous understanding has not yet been reached. Currently, a number of researchers consider this concept from different perspectives, but they all have one goal: uniform application of the rule of law.

An analysis of the studies available in this area shows that many of them relate to the theory of law (Sukhov, 2004; Yarmukhamedov, 2007; Kuznetsov, 2017), while others relate to the branches of law that are not related to the criminal law direction (Barkanov, 2005; Samigullina, 2015). Numerous scientific works have been devoted specially to conflicts in the law branches of the criminal cycle, including criminal, criminal procedure, and criminal executive (Krymov, 2013; Skyba \& Skorik, 2017; Skiba, 2018). However, the indicated issues are usually addressed by researchers in relation to a specific publication (Volkov, 2013; Garmyshev, 2016).

Despite numerous studies of the issues of legislation and law related to conflicts, as well as the legislator's attempts to eliminate them, nevertheless, some difficulties arise due to their presence when making legally significant decisions. This is especially manifested in cases where the interests of opposing parties - participants in legal relations - collide. These and other circumstances necessitate the identification and analysis of certain conflicts in the criminal and executive criminal law.

\section{Methods}

The methodological basis of this study includes the dialectical method. The authors used special cognition methods: logical and legal; comparative, historical, sociological, system-structural, statistical, analysis and synthesis, as well as legal modelling. 


\section{Results and Discussion}

The concepts of "conflict" or "competition of criminal law norms" are not defined in the current criminal and executive criminal law of the Russian Federation. These terms are widely used in the theory of these sciences and are often interpreted as distinct from each other (Kuznetsov, 2017), but in some sources - as equivalent (Inogamova-Khegay, 2015). Malkov V.P. defines conflict as a discrepancy or contradiction between laws and considers competition as "a state where two or more norms, which coincide or differ in content and are designed to resolve the issue, apply for application during qualification of a specific crime, and the law enforcement agency shall determine the norm giving priority" (Malkov, 1974). Malkov V.P. also indicates that it is impossible to contrast these concepts since there is a certain relationship between them, which is seen in the qualification process itself. The definitions of these concepts in science allow making one general conclusion that both competition and conflict arise when the law has two or more rules governing the same social relation.

Let us give examples of the most striking conflicts in the criminal and executive criminal law.

Conflict 1. In accordance with Article 4 of the CC RF, persons who have committed crimes are equal before the law. Parts 1 and 3 of Art. 60 of the $\mathrm{CC} \mathrm{RF}$ contain provisions on the imposition of just punishment, taking into account the nature and degree of public danger of the crime, the perpetrator's identity, the circumstances mitigating and aggravating the punishment. At the same time, Art. 15 of the CC RF stipulates the court's right to change the category of crime to less serious, but not more than once, subject to the conditions specified in it, which contradicts the principle of justice (Art. 6 of the CC RF).

Taking into account that the legislator does not clearly establish the conditions for the implementation of Part 6 of Art. 15 of the CC RF, their application by the court in one case and non-application in another is a violation of the principles of justice and equality of everyone before the law, as well as double consideration of mitigating circumstances is inevitable when the crime category is changed.

As for the goals of punishment, they become unattainable in these conditions. By changing the crime category, a judge changes the whole complex of measures aimed at its achievement. In order to keep the balance of goal and punishment, a stricter punishment shall first be imposed, and when the category is changed, return to the framework defined in Art. 60 of the CC RF (Epikhin et al., 2019; Epikhin et al., 2018). 
Elena V. Mischenko, Maxim S. Fabrikov, Elena V. Martynenko, Stanislav E. Martynenko, Viktor M. Smirnov, Gulnara R. Ibraeva y Andrey V. Kosenko

Young People Leisure Activities Transformation During Quarantine Self-Isolation: Characteristics 458 and Regulation Problem.

This conflict can be eliminated by indicating in the article the obligation of the courts to apply it under appropriate conditions, or Part 6 of Art. 15 should be deleted from the CC RF.

Conflict 2. Fine is a common form of punishment not related to isolation from society and imposed on minors. Changes made to Part 2 of Art. 88 of the CC RF by the Federal Law No. 162-3 dated December 8,2003 , significantly affected the fine imposition practice. A fine began to be imposed both in the presence of a convicted minor having his/her own independent earnings or property that may be charged and, in the absence, thereof. In this case, a fine may be charged from his/her parents or other legal representatives with their consent by a court decision. This provision of the law is criticized by some researchers (Nechaeva, 2016). These changes significantly expanded the courts' abilities to impose a fine on minors. Over the past five years, the average percentage of fines has been $11.3 \%$ (up to 2003 $0.7 \%$ ) (// http://www.cdep.ru). This indicator grew because the fine had begun to be charged most often from parents or legal representatives. This provision violates the most important principle of individual guilty (personal) responsibility (Art. 5 of the CC RF).

Following the legislator's logic applied in the CC RF, it is possible to stipulate the possibility of imposing other forms of punishment on minors' parents with their consent in the same way. The absurdity of such a situation is obvious.

A fine can indeed be an effective punishment, but only if the minor is personally responsible for the crime (Nechaeva, 2016).

Conflict 3. The convicted persons execute (serve) their punishment with the obligation to undergo treatment for alcoholism and drug addiction carried out by medical correctional institutions (hereinafter - MCI). To date, the legal status of MCI is not fully defined. As a place of liberty deprivation, it is mentioned in Part 1 of Art. 56 of the CC RF. However, Art. 58 of the CC RF established a procedure for determining the type of correctional institution for specific categories of convicts, but this procedure for MCI is not specified in this article. We believe that the indicated categories of convicts should be defined in the CC $\mathrm{RF}$ for $\mathrm{MCO}$, as well as for other correctional institutions.

Conflict 4. According to the content of Art. 53.1 of the CC RF, forced labor is an intermediate punishment between imprisonment and punishments not related to the isolation of the convicted person from society, which allows making a conclusion that they can be considered as more severe punishment than restriction of freedom, but milder than imprisonment. The issue of the independence of this punishment is doubtful. According to the above article, forced labour is used as an alternative to imprisonment. The grounds for the application are clearly defined in the CC RF. In accordance with Part 2 of Art. 53.1 of the CC RF, if, having imposed a sentence of imprisonment, the court finds that the convicted person may be 
corrected without serving a sentence in prison, it replaces the sentence of imprisonment with forced labor.

The fact of sentencing, first in the form of imprisonment, and then replaced with forced labor, undermines the status of forced labor as an independent form of punishment (Nechaeva, 2018).

But there are other contradictions. In accordance with Part 7 of Art. 53.1 of the CC RF and Part 1 of Art. 88 of the CC RF, forced labor is not applied to minors. At the same time, the provisions of Part 3 of Art. 49, Part 4 of Art. 50, Part 5 of Art. 53 do not exclude the possibility of replacing punishment for a minor convicted person who maliciously evades serving the sentences specified in the above norms with imprisonment. It turns out that for there is a replacement, for example, of corrective labor to forced labor, for adult convicted persons, but not for minors. For minors, the specified punishments can only be replaced with imprisonment, which puts them in unequal conditions compared to adult convicted persons. It is necessary to amend the relevant articles of the $\mathrm{CC} \mathrm{RF}$, which would stipulate the possibility of imposing punishment in the form of forced labour for minors (Krymov, 2013).

Conflict 5. Let us analyze the content of Part 9 of Art. 16 of the CEL RF, Art. 74, 77 and 77.1 of the CEL RF. Part 9 of Art. 16 of the CC RF establishes a list of types of institutions that can be chosen for imprisonment, including pre-trial detention centers (hereinafter - the PTDC) in relation to convicted persons specified in Art. 77 of the CC RF, that is, left to perform maintenance of PTDC and prisons. However, Part 1 of Art. 74 of the CC RF contains five categories of convicted persons, who may be held in PTDC: 1) those left to perform maintenance; 2) in respect of whom the court verdict has entered into force and who will be sent to correctional institutions to serve their sentences; 3) those moved from one place of serving a sentence to another; 4) those left in PTDC or transferred to PTDC in the manner prescribed by Art. 77.1 of the CC RF; 5) persons sentenced to a term of not more than six months, left in PTDC with their consent.

As we can see, this conflict should be eliminated, for example, by making appropriate changes to Part 9 of Art. 16 of the CEL RF.

Conflict 6. In accordance with Part 4 of Art. 58 of the CC RF, the type of correctional institution is changed by the court in accordance with the CEL RF (Part 5 of Art. 78 of the CEL RF)

However, Art. 77 of the CEL RF establishes that the convicted persons should be left in PTDC to carry out maintenance by order of the head, which contradicts the above standards. The decision to leave the convicted persons in PTDC for maintenance should be made by the courts, as required by Part 5 of Art. 78 of the CEL RF and Part 4 of Art. 58 of the CC RF, because the type of correctional institution is actually changed. This also applies to MCI (Nechaeva, 2013). 
Elena V. Mischenko, Maxim S. Fabrikov, Elena V. Martynenko, Stanislav E. Martynenko, Viktor M. Smirnov, Gulnara R. Ibraeva y Andrey V. Kosenko

Young People Leisure Activities Transformation During Quarantine Self-Isolation: Characteristics 460 and Regulation Problem.

\section{Conclusions}

The issue considered represents the coverage of a wide range of criminal law and criminal executive issues. Therefore, it cannot be resolved within the framework of a single scientific article. The authors tried to highlight the shortcomings of only a small aspect of the issue - criminal and criminal executive law conflicts and ways of overcoming them. Further systematic investigation of the conflict issue is necessary with the expansion of the list of analyzed regulatory legal acts.

\section{Acknowledgements}

The work is performed according to the Russian Government Program of Competitive Growth of Kazan Federal University

\section{Bibliographic References}

BARKANOV, Andre, S. 2005. Conflicts of private and public law in regulating the distribution of funds received from the entrepreneurial activity: abstract of a thesis for the Candidate of Law. University of Nizhny Novgorod. Nizhny Novgorod, Russia.

EPIKHIN, Alexander Yu; ZAYTSEV, Oleg A; TASAKOV, Sergei V; NECHAEVA, Elena V; MUKHAMETSHIN, Timur R. 2018. "The Correctional Process in Russian Penitentiary Institutions" In: The Journal of Social Sciences Research. No. 1, pp. 183-186.

EPIKHIN, Alexander Yuryevich; ZAITSEV, Oleg Aleksandrovich; TASAKOV, Sergei Vladimirovich; NECHAEVA, Elena Vladimirovna; MISHIN, Andrey Viktorovich; ALIYEVA, Gulnar Isaevna. 2019. "The Purpose of «Correction" in the Russian Criminal and Criminal and Executive Law" In: Journal of Politics and Law. Vol. 12, No. 5, pp. 12-29.

GARMYSHEV, Yaroslav V. 2016. "To the issue of classifying some evaluative concepts in Russian criminal law" In: Criminology Journal of Baikal National University of Economics and Law. Vol. 10, No. 4, pp. 732-739.

INOGAMOVA-KHEGAY, Lillana V. 2015. Conceptual basis of competition of the criminal law norms: monograph. Norma. Moscow, Russia. 
KRYMOV, Alexander A. 2013. "Conflicts of criminal, criminal procedure and criminal executive law at the stage of sentence execution" In: Bulletin of the Vladimir Law Institute. Vol. 4, No. 29, pp. 111-113.

KUZNETSOV, Alexander P. 2017. "Conflicts in law: theoretical study. Legal technique No. 11" In: Legal statistics. Available online. In: http://www. cdep.ru. Consultation date:12/04/2019.

MALKOV, Villia.P. (1974). The aggregate of crimes. Kazan Publication, Kazan/ Russia, p. 178.

NECHAEVA, Evgeniya V. 2013. Organizational and legal aspects of punishment execution in relation to convicted persons held in the pre-trial detention centres. Cheboksary: Publishing House of the Chuvash University. Cheboksary, Russia.

NECHAEVA, Evgeniya V. 2016. "The system of punishments for minors needs improvement. Jurisprudence and practice" In: Bulletin of the Nizhny Novgorod Academy of the Ministry of Internal Affairs of Russia. Vol. 3, No. 35, pp. 71-76.

NECHAEVA, Evgeniya V. 2018. "Prospects for punishment transformation in the form of forced labor" In: Criminal Executive Law. Vol. 13, No. 1, pp. 45-49.

SAMIGULLINA, Andrea, V. 2015. "Conflicts of labor legislation. Bulletin of Arbitration” In: Practice. Vol. 2, No. 57, pp. 35-40.

SKIBA, Andrey P. 2018. "Conflicts and other shortcomings of the law when applying criminal penalties for minors. Social and legal protection of childhood as a priority area of modern public policy" In: Collection of the International Scientific and Practical Conference. No. 28-29 june, Almalybak/ Kazakhstan, pp. 553-561.

SKYBA, Andre, P; SKORIK, Elena N. 2017. "Issues of decision-making on sentence execution: conflicts of criminal, criminal executive and criminal procedural law" In: Bulletin of the Moscow State Linguistic University. Education and pedagogical sciences. Vol. 6, No. 785, pp. 226-234.

SUKHOV, Esuhov, V. 2004. Legal conflicts and methods for resolving them: abstract of a thesis for the Candidate of Law. University of Nizhny Novgorod. Nizhny Novgorod, Russia.

UFIMTSEVA, Valladir, A. 2019. "Conflict criminal law in the history of domestic legislation" In: Historical and legal problems: a new perspective. No. 4, pp. 132-141. 
Elena V. Mischenko, Maxim S. Fabrikov, Elena V. Martynenko, Stanislav E. Martynenko, Viktor M. Smirnov, Gulnara R. Ibraeva y Andrey V. Kosenko

Young People Leisure Activities Transformation During Quarantine Self-Isolation: Characteristics and Regulation Problem.

VOLKOV, Kirill Alexandrovich. 2013. "Police crime counteraction activity: conflict of laws on legal regulation of justifiable defense and criminal custody" In: Criminology Journal of Baikal National University of Economics and Law. No. 2, pp. 81-87.

YARMUKHAMEDOV, Rayan F. 2007. Conflicts of law enforcement (theoretical and historical aspect): abstract of a thesis for the Candidate of Law. Kuban State University. Krasnodar, Russia. 


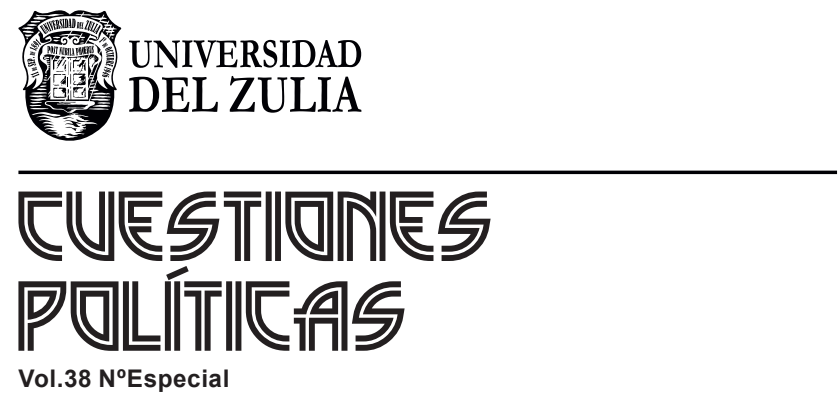

www.luz.edu.ve 